\title{
ALGAE AND CYANOBACTERIA ON PAINTED SURFACES IN SOUTHERN BRAZIL
}

\author{
Peter M. Gaylarde; Christine C. Gaylarde* \\ Microbiological Resources Center-MIRCEN, Departamento de Solos, Universidade Federal do \\ Rio Grande do Sul-UFRGS, Porto Alegre, RS, Brasil
}

Submitted: May 28, 1999; Returned to authors for corrections: June 29, 1999; Approved: July 30, 1999

\begin{abstract}
Algae and cyanobacteria disfigure the external surfaces of buildings and may cause their physico-chemical deterioration. Even though the climate in Brazil is humid, there is no published literature on this problem. The objective of this work was to identify the major phototrophs present on Brazilian constructions in residential, urban and rural sites. The algal and cyanobacterial types present on discolored surfaces of painted buildings in nine different municipalities in Brazil, all lying between latitudes $19^{\circ}$ South and $30^{\circ}$ South, were examined. A total of 816 different organisms was detected in 58 sites. Approximately $63 \%$ were single-celled or colonial organisms. The cyanobacterial genus, Synechocystis, was the most biodiverse and frequently comprised the major biomass. It was present in $63.4 \%$ of sites. Second and third most frequently detected were Oscillatoria and the algal genus, Chlorella, respectively. The latter organism showed the most widespread occurrence $(72.4 \%)$. Cyanobacteria were the most important colonizers, especially at urban sites, where over $62 \%$ of the organisms detected belonged to this class. Filamentous phototrophs were found in smaller numbers than non-filamentous at all locations.
\end{abstract}

Key words: algae, biodeterioration, Brazil, cyanobacteria, paint films

\section{INTRODUCTION}

The growth of phototrophic microorganisms, algae and cyanobacteria, on the external surfaces of buildings can cause discoloration and physicochemical deterioration. The main consequences of such growth are disfigurement, retention of water (5), encouragement of colonization by macroorganisms and, in some cases, corrosion caused by organic acids (9). Such problems are particularly important in humid climates (1). Nevertheless, there is no published information on algae growing on buildings in Brazil, or, indeed, in Latin America. Information on algae present on building surfaces in countries with humid climates is restricted to Singapore (19) and India (11). However, these countries differ from Brazil in many respects and it is important to know the types of organisms present in such ecosystems in Brazil, if rational procedures of control are to be applied.

Two books have been recently published on algae in Southern Brazil. Garcia-Baptista (7) identified the algae present on a beach in Northern Rio Grande do Sul. The major psammic colonizers were diatoms, but 11 cyanobacterial and eight algal genera were also identified. Francesschini (6) studied various freshwater sites in Porto Alegre - RS, and identified 48 cyanobacterial species, 65 euglenophyta, 2

\footnotetext{
* Corresponding author. Mailing Address: MIRCEN, Departamento de Solos, UFRGS, Caixa Postal 776, CEP 90001-970, Porto Alegre, RS, Brasil. Fax (+5551) 316-6029. E-mail chrisg@vortex.ufrgs.br
} 
pyrrhophyta, 25 chromophyta (excluding diatoms) and 213 chlorophyta. The main aquatic chlorophyta were Chlamydomonas, Volvox, Botryococcus, Coelastrum, Scenedesmus, Pediastrum, Klebsormidium, Ulothrix, Uronema, Microspora, Bulbochaete and Oedogonium. Obviously, these data cannot be extrapolated to the environment of external building surfaces, where sub-aerial algae are the colonizing phototrophic microorganisms.

The present investigation aimed to show whether there is any similarity between water and sand phototrophic microorganisms and those present on painted walls in Southern Brazil, and to provide information on the types present in the latter ecosystem.

\section{MATERIALS AND METHODS}

Sampling. Samples were taken aseptically from the external surfaces of selected buildings in the Brazilian states of Rio Grande do Sul (RS), Santa Catarina (SC), Mato Grosso do Sul (MS) and São Paulo (SP). Samples were obtained from urban sites in Porto Alegre, RS; Lages, SC; Florianopolis, SC; Corumba, MS and São Paulo, SP, from residential locations in Porto Alegre, RS; Gravatal, SC; Lagoa de Conceicão, SC; Bonito, MS and São Paulo, SP, and from rural sites in Porto Alegre, RS; Atlantida, RS; Porto Belo, SC and Pereque, SC. All these lie between latitudes $19^{\circ}$ South and $30^{\circ}$ South. Sampling techniques used included the adhesive tape method which has been much used for fungal sampling (15), the contact plate method, scraping with a sterile scalpel and removal of flaking paint with sterile forceps, depending on the state of the painted surface. Buildings with obvious lichen growth were not sampled.

Detection and identification techniques. Samples were incubated, under standard, low-light, conditions, on solid media for algae (Modified Knop's medium - MKM; 8) and cyanobacteria (BG11; 16). Adhesive tape and paint flake samples were examined directly, with low power binocular and high power optical microscopes, in addition to incubating on solid media. After growth, subcultures were made on solid media and in liquid MKM. Identification was by microscopic examination (light and fluorescence microscopy), the iodine test for starch, pigment extraction with methanol followed by fluoroscopy, and growth on nitrogen-free media.
Cyanobacteria were principally classified according to Bergey's Manual (10).

The algae were classified according to Belcher and Swale (3) and Prescott (13), with additional reference to Smith (17), Prescott (14) and Bicudo and Bicudo (4). The identification of all organisms was to genus level, where possible. Some families, such as the Trentepohliaceae, were not divided into genera, since the development of the morphological characteristics required for identification, even at the genus level, requires prolonged unialgal culture under various conditions.

A total of 58 sites were sampled during the months of February to July (RS, SC and MS) and in December (SC), and analyzed.

\section{RESULTS AND DISCUSSION}

\section{Culture methods}

After the first two months the use of BG11 was discontinued for the following reasons:

1. BG11 allowed the growth of considerably more groups of microorganisms than the algal medium. Apart from algae and cyanobacteria, relatively good growth of fungi (basidiomycetes, ascomycetes, aquatic and terrestrial phycomycetes and slime molds), gliding bacteria and actinomycetes was noted.

2. The range of algae and cyanobacteria appearing on MKM was equal to or greater than that on BG11 and growth appeared earlier on MKM than on BG11.

Organisms were identified to genus level, where possible, based on their morphological characteristics. Very few organisms were obtained in pure culture, owing to the complexity of the biofilms on these painted surfaces. Not only algae and cyanobacteria, but also protozoa, fungi, slime molds, actinomycetes and other bacterial groups were observed. These organisms frequently kill many of the algae and blue-green bacteria in laboratory cultures, and for this reason morphological identification in short-term (1, 2, 3 and 4 day) culture was adopted, followed by continued regular examination up to 4 weeks. The large variety of types found in this study in comparison with other published data $(11 ; 19)$ is almost certainly due to this strategy. 
Observations showed that a succession of protozoa, bacteria and fungi occurs in these cultures. Protozoa may the most important components, grazing on bacteria, algae and fungi. Few other cell types remained in some cultures after 2-3 weeks, but protozoa were not present at all sites. Ciliates were often the dominant protozoa in the first $48 \mathrm{~h}$ of culture, but were normally replaced later by other types. Competition and succession were observed on almost all plates, indicating that only sequential observations can reliably detect the range of organisms reported here. Traditional culture techniques result in the detection of many fewer types from each sample. Filamentous cyanobacteria, Chlorella and Trentepohlia were more frequent in late cultures and, in the worst cases, all other phototrophic genera seen in the initial growth were lost from the plates or liquid cultures after extended incubation. For example, in a sample which yielded 15 genera after $48 \mathrm{~h}$ incubation, only Chlorella was detected after two weeks, and yet this genus was not seen when the sample was examined after $48 \mathrm{~h}$ incubation.

\section{Microorganisms detected}

Table 1 shows the numbers of different phototrophic microorganisms detected at all sites. A total of 816 different organisms was detected in the 58 sites. Of these, approximately $63 \%$ were singlecelled or colonial algae and cyanobacteria. Around 1.5 times as many cyanobacteria of Bergey's Groups 1 and 2 (10) were detected as of the other (filamentous) groups and for the algae the difference was even greater, 3.5 times as many single-celled or colonial forms as filamentous algae.

The preponderance of non-filamentous cyanobacteria is somewhat surprising, in view of previously published data. Joshi and Mukundan (11) showed that cyanobacteria were the dominant photosynthetic organisms present on surfaces painted with acrylics, cement-based coatings and oil-based enamels in India and that filamentous cyanobacteria were the most frequent isolates. Plectonema (stated in Bergey (10) to be of uncertain classification, either Group 3 or Group 4) was found in $60 \%$ of samples, with Lyngbya and Nostoc being the next most abundant groups. Although Wee and Lee (19) reported that Anacystis, now classified as Synechocystis (10), was present on over 50\% of walls and buildings in Singapore, the most frequent phototroph occurring was Trentepohlia. They found
Table 1 - Analysis of phototrophs detected on painted surfaces at 20 residential, 14 urban and 24 rural sites in Brazil.

\begin{tabular}{|c|c|c|c|c|}
\hline & Total & Residential & Urban & Rural \\
\hline $\begin{array}{l}\text { Total number of } \\
\text { different types }\end{array}$ & 816 & 270 & 211 & 335 \\
\hline Mean $\mathrm{N}^{\circ}$ per site & 14.07 & 13.5 & 15.07 & 13.96 \\
\hline $\begin{array}{l}\text { Mean } \mathrm{N}^{\circ} \text { of algae } \\
\text { per site }\end{array}$ & 6.28 & 6.8 & 5.71 & 6.17 \\
\hline $\begin{array}{l}\text { Mean } \mathrm{N}^{\circ} \text { of } \\
\text { cyanobacteria } \\
\text { per site }\end{array}$ & 7.79 & 6.7 & 9.38 & 7.79 \\
\hline $\begin{array}{l}\text { Mean } \mathrm{N}^{\circ} \text { of } \\
\text { non-filamentous } \\
\text { cyanobacteria } \\
\text { per site }\end{array}$ & 4.59 & 3.95 & 5.07 & 4.83 \\
\hline $\begin{array}{l}\text { Mean } \mathrm{N}^{\mathrm{o}} \text { of } \\
\text { non-filamentous } \\
\text { algae per site }\end{array}$ & 4.86 & 5.35 & 4.79 & 4.5 \\
\hline $\begin{array}{l}\text { Mean } \mathrm{N}^{\circ} \text { of } \\
\text { filamentous } \\
\text { cyanobacteria } \\
\text { per site }\end{array}$ & 3.21 & 2.75 & 4.29 & 2.96 \\
\hline $\begin{array}{l}\text { Mean } \mathrm{N}^{\mathrm{o}} \text { of } \\
\text { filamentous algae } \\
\text { per site }\end{array}$ & 1.41 & 1.45 & 0.93 & 1.67 \\
\hline
\end{tabular}

T. odorata on $66 \%$ of walls sampled and this genus has since been accepted as the sole standard organism for use in the Singapore Standard test method for algicidal paints (2). The results of our survey suggest that this is not an appropriate organism for a singleorganism test in Brazil, as the Ulotrichaceae are the most commonly occurring filamentous green algae in our samples (Table 2). Trentepohliaceae were isolated from 16 of 58 sites ( $27.6 \%$ as compared with $48.3 \%$ for Ulotrichaceae). In only one site containing Trentepohliaceae was the pained surface stained orange or red, although this is regarded as typical of the surface growth of this group (12). Black, gray, green, or occasionally brown staining was present. The first three are the predominant colors on soiled painted surfaces in S. Brazil. The other, rare, examples of orange discoloration seen proved to be mineral or fungal in origin, or associated with the presence of pigmented sheathed filamentous cyanobacteria, mainly Scytonema, and with unidentified coccoid cyanobacteria with heavily pigmented capsules.

The genus which showed highest diversity in our samples was Synechocystis, with 143 detections. This was present at $63.4 \%$ of sampled sites and was often 
Table 2 - Major types of phototrophs detected on painted surfaces at 20 residential, 14 urban and 24 rural sites in Brazil.

\begin{tabular}{lrrrr}
\hline Type & Total & Residential & Urban & Rural \\
\hline Total cyanobacteria & $\mathbf{4 5 2}$ & $\mathbf{1 3 4}$ & $\mathbf{1 3 1}$ & $\mathbf{1 8 7}$ \\
Synechocystis & 143 & 42 & 30 & 71 \\
Oscillatoria & 58 & 17 & 19 & 22 \\
Lyngbya & 44 & 11 & 17 & 16 \\
Synechococcus & 35 & 12 & 15 & 8 \\
Gloeocapsa & 33 & 10 & 6 & 17 \\
Gloeothece & 29 & 13 & 8 & 8 \\
Nostocaceae & 23 & 9 & 3 & 11 \\
Total algae & $\mathbf{3 6 4}$ & $\mathbf{1 3 6}$ & $\mathbf{8 0}$ & $\mathbf{1 4 8}$ \\
Chlorella & 55 & 19 & 14 & 22 \\
Ulotricaceae & 51 & 16 & 10 & 25 \\
Chlorococcum & 37 & 13 & 9 & 15 \\
Eustigmatos & 28 & 8 & 10 & 10 \\
Trentepohliaceae & 26 & 9 & 2 & 15 \\
Trebouxia & 20 & 10 & 2 & 8 \\
Bacilliarophyta & 15 & 7 & 4 & 4 \\
Xanthophyta & 13 & 7 & 0 & 6 \\
\hline
\end{tabular}

the major biomass; hence it could be an appropriate genus from which to select an organism for standard tests. It must be pointed out, however, that a very wide range of morphological types of Synechocystis was seen in our biofilms, indicating many different species. Classical botanical classification divides this group into different genera (Aphanocapsa, Microcystis, etc.), but Stanier et al. (18) emphasized the inconsistencies of this approach and it has not been adopted here.

The only green algae isolated by Joshi and Mukundan (11) from acrylic painted surfaces in India were Trebouxia and Chlorella and the latter organism was our most frequent phototrophic genus (Table 2), present in $72.4 \%$ of sites. Wee and Lee (19) found only $6 \%$ occurrence of this algal genus in Singapore, once again emphasizing the differences between these two humid climates.

There is little relationship between the phototrophic microorganisms detected on these painted walls and those found in water or on sand in S. Brazil $(7 ; 6)$, indicating that this is a completely different ecosystem, governed by its own specific factors. The most important of these may be frequent desiccation and rehydration of the biofilm. Microorganisms on walls have to withstand such variations, in addition to very high temperatures in the summer months. The factors determining the biodiversity of this unusual and very understudied ecosystem deserve more attention.

\section{ACKNOWLEDMENT}

We wish to thank THOR CHEMICALS LTD., of São Paulo and the UK, for partially funding this work.

\section{RESUMO}

\section{Algas e cianobactérias em superfícies pintadas no Sul do Brasil}

Algas e cianobactérias produzem coloração nas superfícies externas de construções e podem causar a sua deterioração físico-química. Apesar a clima úmida do Brasil, não existe no pais uma literatura sobre este problema. O objetivo deste trabalho foi identificar os microrganismos fototróficos mais importantes nas superfícies de construções, em áreas residenciais, urbanas e rurais do Brasil. Foram avaliados os tipos de algas e cianobactérias presentes em superfícies pintadas coloradas, em nove municípios do Brasil localizados entre $19^{\circ}$ Sul e $30^{\circ}$ Sul. Aproximadamente $63 \%$ destes foram células simples, ou organismos coloniais. O gênero, Synechocystis, foi o organismo que mostrou-se o mais diverso e, frequentemente, compõe a maior parte da biomassa, foi detectado em $63,4 \%$ das amostras. Outros organismos frequentemente detectados foram os gêneros Oscillatoria e Chlorella. Este último se destacou como o organismo de maior ocorrência $(72,4 \%)$. As cianobactérias foram muito comuns, especialmente em locais urbanos, sendo que, nestas amostras, maior que $62 \%$ dos organismos detectados pertenceu a este classe. Organismos fototróficos filamentosos foram detectados em menor número do que os não filamentosos em todas as amostras.

Palavras-chave: algas, biodeterioração, Brasil, cianobactérias, tintas

\section{REFERENCES}

1. Allsopp, D.; Seal, K.J. Introduction to Biodeterioration, Edward Arnold, London, 1986.

2. Anon. Specification for algae resistant emulsion paint for decorative purposes. Singapore Standard 345:1990, Singapore Institute of Standards and Industrial Research, Singapore, 1990.

3. Belcher, H.; Swale, E. A beginner's guide to freshwater algae. H.M. Stationery Office, London, 1977.

4. Bicudo, C.E.M.; Bicudo, R.M.T. Algas de Águas Continentais Brasileiras, São Paulo, Funbec, 1970. 
5. Bravery, A.F. Biodeterioration of paint - a state-of-the-art comment. In Biodeterioration 7, eds. Houghton, D.; Smith, R.N. and Eggins, H.O.W., Elsevier Applied Sci., Barking, 1988, pp. 466-485.

6. Francesschini, I.M. Algues d'eau douce de Porto Alegre, Bresil (les Diatomophycees exclues), Cramer, Berlin, 1992.

7. Garcia-Baptista, M. Psammic Algae from Praia Azul, Cramer, Berlin, 1993.

8. Gaylarde, P.M.; Gaylarde, C.C. A rapid method for the detection of algae and cyanobacteria on the external surfaces of buildings. In LABS 3 Biodegradation and Biodeterioration in Latin America, eds. Gaylarde, C.C.; Barbosa, T.C.P. and Gabilan, N.H., The British Phycological Society, UK, paper $n^{\circ} 37,1998$.

9. Gillatt, J.W. The need for antifungal and antialgal additives in high performance surface coatings. Surface Coatings Internat. 74: 6-12, 1991.

10. Holt, J.G.; Krieg, N.R.; Sneath, P.H.A.; Staley, J.T. \& Williams, S.T. Bergey's Manual of Determinative Bacteriology, 9th ed., Baltimore, Williams \& Wilkins, 1994.

11. Joshi, C.D.; Mukundan, U. Algal disfigurement and degradation of architectural paints in India. Paintindia 47: 27-32, 1997.
12. Lee, K.B.; Wee, Y.C. Algae growing on walls around Singapore. Malay. Nat. J. 35: 125-132, 1982.

13. Prescott, G.W. The Fresh-water Algae, Dubuque (Ohio), Wm. C. Brown Co., 1964.

14. Prescott, G.W. The Algae, Houghton Mifflin, Boston, 1968.

15. Raty, K.; Raatikainen, O.; Holmalahti, J. et al. Biological activities of actinomycetes and fungi isolated from the indoor air of problem houses. Internat. Biodet. Biodeg. 34: 143-154, 1994.

16. Rippka, R.; Deruelles, J.; Waterbury, J.B.; Herdman, M.; Stanier, R.Y. Generic assignments, strain histories and properties of pure cultures of cyanobacteria. J. Gen. Microbiol. 111: 1-61, 1979.

17. Smith, G.M. Freshwater algae of the United States. McGrawHill, New York, 1950.

18. Stanier, R.Y.; Sistrom, W.R.; Hansen, T.A. et al. Proposal to place the nomenclature of the cyanobacteria (blue-green algae) under the rules of the International Code of Nomenclature of Bacteria. Internat. J. Systemat. Bacteriol. 28: 335-336, 1978.

19. Wee, Y.C.; Lee, K.B. Proliferation of algae on surfaces of buildings in Singapore. Internat. Biodet. Bull. 16: 113-117, 1980. 